\title{
West Java Water Sustainability Index - A Case Study on Citarum Catchment
}

\author{
I. Juwana $^{a}$, N. Muttil ${ }^{a}$ and C. Perera ${ }^{b}$ \\ ${ }^{a}$ School of Engineering and Science \\ ${ }^{b}$ Faculty of Health, Engineering and Science \\ Victoria University, Melbourne Victoria, AUSTRALIA \\ E-mail: iwan.juwana@live.vu.edu.au
}

\begin{abstract}
In the last decade, the provincial government of West Java has implemented various programs to improve the performances of the water resources in West Java catchments. However, these programs were not successful. It is believed that the main cause for the failure of the programs is the lack of awareness of the people of West Java on the importance of water resources. In general, people in West Java are not aware that those valuable water resources are deteriorating and need to be sustained.
\end{abstract}

It is therefore important to obtain a comprehensive understanding on the current status of water resource conditions in West Java. Once the information on the current conditions of the water resources is obtained, relevant programs can be designed to improve the quality of the water resources. A water sustainability index is a useful tool to address the above issues, as it offers the following benefits:

- It can be used to identify all factors contributing to the improvement of water resources, so that the resources can be used to satisfy the present and future needs.

- It can be used to assist decision makers to prioritise issues and programs related to water resource management.

- It can be used to communicate the current status of existing water resources to the wider community.

The West Java Water Sustainability Index (WJWSI) was developed to address the above issues related to West Java water catchments. This paper discusses the application of WJWSI in the Citarum catchment. It outlines the tasks for developing WJWSI and highlights the results of its application, which will be the basis for recommendations suggested to the relevant authorities. The tasks for developing the WJWSI include the development of conceptual framework and the application of the Delphi technique to refine the conceptual framework. After the application of the Delphi technique, the framework was then finalised with an in-depth interview with key stakeholders.

In the application of WJWSI, the continuous rescaling and categorical scaling methods were used for obtaining sub-index values of the indicators and sub-indicators. The continuous rescaling method was used to obtain the sub-indices of non-qualitative indicators, whereas the categorical scaling method was used to obtain the sub-indices of qualitative indicators. Using the continuous rescaling method, maximum and minimum threshold values for each indicator or sub-indicator were identified. To use the categorical scaling method, categories and criteria for each indicator or sub-indicator were developed.

The results showed that five out of thirteen indicators and sub-indicators used in WJWSI had low sub-index values. Those five indicators and sub-indicators were Water Availability, Water Quality, Education, Water Loss and Poverty. Due to their poor performances, these indicators and sub-indicators need higher priority of actions. Therefore, based on the application, recommendations are suggested to the relevant authorities in the Citarum catchment to prioritise these indicators and sub-indicators in the improvement of water resource management in West Java.

Keywords: Sustainability index, Citarum catchment, West Java, Indonesia. 


\section{INTRODUCTION}

In general, the availability of water resources in West Java, Indonesia, is abundant. However, as the resources have not been managed properly, water shortages are found in some areas of West Java. In terms of quality, water is mostly polluted by domestic, agricultural and industrial activities. For rivers in particular, regular monitoring by the West Java Environmental Protection Agency (EPA) shows that most water quality parameters fall below the threshold values set by provincial and national governments (Wangsaatmaja, 2004). It is therefore critical to identify all factors contributing to the sustainability of these water resources in West Java. A water sustainability index can be used as a tool to identify all factors contributing to the improvement of water resources (Chaves and Alipaz, 2007; Policy Research Initiative, 2007; Sullivan, 2002). The index can also be used to assist decision makers to prioritise issues and programs related to water resource improvement. In addition, it will be useful to communicate the current status of existing water resources to the community (Policy Research Initiative, 2007).

Even though there have been some successful experiences with the implementation of the existing water sustainability indices for the regions they have been developed, these indices may not be fully applicable in other regions or in other countries (Loucks et al., 2000). Therefore, a new water sustainability index called West Java Water Sustainability Index (WJWSI) was developed for use in Indonesia, in particular in West Java (Juwana et al., 2010a). The paper outlines the tasks for developing WJWSI, discusses its application and highlights the results of the application to one of the West Java catchments, the Citarum catchment. At the time of the application, the latest available data for the Citarum catchment was for 2008. Therefore, all relevant calculations in this study were based on this particular year. Based on the results, recommendations are suggested to the relevant authorities.

\section{TASKS UNDERTAKEN TO DEVELOP THE WJWSI}

To develop the WJWSI, the following tasks were undertaken: (i) Development of conceptual framework to identify an initial set of WJWSI components, indicators/sub-indicators and threshold values (Juwana, et al., 2010a), and (ii) Application of the Delphi technique to finalise the index (Juwana et al., 2010b).

The initial set of components and indicators was done specifically keeping in mind the water resources, environmental, social and economic characteristics of West Java. At the same time, it considered the universally available concepts and guidelines on water resources and sustainability, and also reflected upon the components used in the existing water sustainability indices of Water Poverty Index (WPI) (Sullivan and Meigh, 2007), Canadian Water Sustainability Index (CWSI) (Policy Research Initiative, 2007) and Watershed Sustainability Index (WSI) (Chaves and Alipaz, 2007).

This conceptual framework was then refined through the application of the Delphi technique and an in-depth interview to develop the final framework of WJWSI. The Delphi technique is a method to extract opinion from identified stakeholders, and to reach consensus among the stakeholders, through multiple rounds of questionnaire distribution (Delbecq et al., 1975; Toward and Ostwald, 2002). The respondents for the Delphi application were stakeholders from
Table 1. Final Framework of WJWSI after the In-depth Interview

\begin{tabular}{|c|c|c|c|c|c|}
\hline \multirow[t]{2}{*}{ Component } & \multirow[t]{2}{*}{ Indicator } & \multirow{2}{*}{$\begin{array}{c}\text { Sub- } \\
\text { indicator }\end{array}$} & \multirow[t]{2}{*}{ Unit } & \multicolumn{2}{|c|}{$\begin{array}{l}\text { Threshold } \\
\text { values }\end{array}$} \\
\hline & & & & Max & Min \\
\hline \multirow{3}{*}{ Conservation } & $\begin{array}{l}\text { Water } \\
\text { Availability }\end{array}$ & & $\mathrm{m}^{3} / \mathrm{cap} / \mathrm{yr}$ & $\begin{array}{c}1700 \\
a\end{array}$ & $500^{b}$ \\
\hline & $\begin{array}{l}\text { Land Use } \\
\text { Changes }\end{array}$ & & $\%$ & $100^{\mathrm{b}}$ & $0^{\mathrm{a}}$ \\
\hline & Water Quality & & - & $0^{\mathrm{a}}$ & $-31^{\mathrm{b}}$ \\
\hline \multirow{3}{*}{ Water Use } & $\begin{array}{l}\text { Water } \\
\text { Demand }\end{array}$ & & $\%$ & $40^{b}$ & $10^{\mathrm{a}}$ \\
\hline & \multirow{2}{*}{$\begin{array}{l}\text { Water Service } \\
\text { Provision }\end{array}$} & Coverage & $\%$ & $80^{\mathrm{a}}$ & $0^{\mathrm{b}}$ \\
\hline & & Water Loss & $\%$ & $30^{b}$ & $15^{\mathrm{a}}$ \\
\hline \multirow{7}{*}{$\begin{array}{l}\text { Policy and } \\
\text { Governance }\end{array}$} & $\begin{array}{l}\text { Information } \\
\text { Disclosure }\end{array}$ & & - & $100^{\mathrm{a}}$ & $0^{\mathrm{b}}$ \\
\hline & $\begin{array}{l}\text { Governance } \\
\text { Structure }\end{array}$ & & - & $100^{\mathrm{a}}$ & $0^{\mathrm{b}}$ \\
\hline & \multirow{4}{*}{$\begin{array}{l}\text { Public } \\
\text { Participation }\end{array}$} & Education & $\%$ & $100^{\mathrm{a}}$ & $0^{\mathrm{b}}$ \\
\hline & & Poverty & $\%$ & $20^{b}$ & $0^{\mathrm{a}}$ \\
\hline & & $\begin{array}{l}\text { Health } \\
\text { Impact }\end{array}$ & $\begin{array}{l}\text { (cases/1000 } \\
\text { population) }\end{array}$ & $2^{\mathrm{b}}$ & $0^{\mathrm{a}}$ \\
\hline & & Sanitation & $\%$ & $100^{\mathrm{a}}$ & $0^{\mathrm{b}}$ \\
\hline & $\begin{array}{l}\text { Law } \\
\text { Enforcement }\end{array}$ & & & $100^{\mathrm{a}}$ & $0^{\mathrm{b}}$ \\
\hline
\end{tabular}

a: preferable; $b$ : not preferable 
university lecturers, governmental officials, environmental consultants and community groups. These respondents were asked to assess, modify and change the components, indicators and threshold values in the conceptual framework. Results from the Delphi application was, then, brought into an in-depth interview with selected key stakeholders to address the indicators and threshold values that have not been agreed during the Delphi application. The final structure of WJWSI is shown in Table 1. This final framework was then applied to the Citarum catchment.

\section{THE CITARUM CATCHMENT}

The Citarum catchment is one of the 40 catchments in West Java. Of these catchments, 22 flow into the northern part of the West Java province and the other 18 flow into the south. The main river in the catchment, the Citarum river, flows across two provinces and several regions. According to the 2006 decree of National Ministry of Internal Affair, Ministry of Forestry and Ministry of Public Works, the Citarum catchment should be prioritised as the catchment has significant impacts on the national development of Indonesia, particularly on the economic sector.

Pressures on the catchment come from pollutants of various activities within the catchment. From the domestic sector, pollutants originate from both direct and indirect discharge of black and grey water of the households. From the industry sector, hundreds of industries along the river pollute the river currently, as there is no appropriate awareness and law enforcement. In addition, agriculture and livestock have also contributed to pollution along the rivers in the catchment.

\section{OBTAINING SUB-INDEX VALUES OF INDICATORS AND SUB-INDICATORS}

To obtain the sub-indices or the index value of indicators and sub-indicators of WJWSI, continuous rescaling and categorical scaling methods are used. The continuous re-scaling method is used to produce an identical range for the values of indicators, e.g. $0-1$ or $0-100$. The categorical method assigns categories for indicators based on some defined criteria. The categories can be numerical (values such as $0-100$ ) or qualitative (such as 'very good', 'good' or 'poor'). Equations used for the continuous re-scaling method is shown in Eq. 1 and Eq. 2, where $S_{i}$ is the sub-index value for indicator $i$ and $X_{i}$ is the actual value for indicator $i$, and $X_{\min }$ and $X_{\max }$ are the minimum and maximum threshold values of the respective indicator.

$$
S_{i}=100-\left(\frac{X_{i}-X_{\min }}{X_{\max }-X_{\min }}\right)
$$

Eq. 1 is used when the $X_{\min }$ of the indicator is the least preferred value and $\mathrm{X}_{\max }$ is the most preferred value, where Eq. 2 is used for the opposite situation. The use of the categorical method (with numerical categories) is shown in Eq. 3, where $\mathrm{Z}_{1}$ or $\mathrm{Z}_{2}$ are categories for $\mathrm{X}_{i}$ that meets criteria 1 or criteria 2 respectively, and $n$ is the number of categories.

$$
S_{i}=\begin{array}{ccc}
Z_{1} & \text { if } & X_{i} \text { meets criteria } 1 \\
Z_{2} & \text { if } & X_{i} \text { meets criteria } 2 \\
\ldots & & \ldots \\
Z_{n} & \text { if } & X_{n} \text { meets criteria } n
\end{array}
$$

In WJWSI there are three groups of indicators and sub-indicators. Indicators and sub-indicators under the first group are Water Availability, Land Use Changes, Coverage, Education and Sanitation. For these indicators and sub-indicators, their $X_{\max }$ and $X_{\min }$ are the most and least preferred values respectively. Therefore, the sub-index values for these indicators and sub-indicators were obtained using Eq. 1.

Indicators and sub-indicators of the second group are Water Quality, Water Demand, Water Loss, Poverty and Health Impact. For these indicators and sub-indicators, their $\mathrm{X}_{\min }$ and $\mathrm{X}_{\max }$ are the most and least preferred values respectively. Therefore, the sub-index values for these indicators and sub-indicators were obtained using Eq. 2. In the third group, there are three indicators which are Information Disclosure, Governance Structure and Law Enforcement. For these indicators, threshold values to calculate sub-indices are not available because of the qualitative nature of these indicators. Therefore, for these indicators the categorical scaling was used to obtain their sub-indices. The criteria used to obtain sub-indices for these categorical indicators are presented as follows:

\section{Information Disclosure}

This indicator examines the availability and accessibility of key data related to water resource management, for public use. A quartile scale was proposed to quantify the sub-index for this indicator (as shown in Table 2). Key data include rainfall,
Table 2. Sub-index for Information Disclosure

\begin{tabular}{|l|c|}
\hline \multicolumn{1}{|c|}{ Criteria } & Sub-index \\
\hline Only few key data are available & $0-<25$ \\
\hline $\begin{array}{l}\text { Key data available, but only few are accessible through } \\
\text { the internet }\end{array}$ & $25-<50$ \\
\hline Key data available, accessible, but not regularly updated & $50-<75$ \\
\hline Key data available, accessible and regularly updated & $75-100$ \\
\hline
\end{tabular}


population, water quality, water use, coverage, water losses, education, poverty, sanitation, diseases and land use

\section{Governance Structure}

This indicator analyses the governance structure of water-related institutions in West Java, particularly with respect to their job descriptions and overlaps among different institutions. A set of criteria and categories, based on a quartile scale, was proposed to quantify the sub-index for this indicator (as shown in Table 3).

\section{Law Enforcement}

This indicator considers the enforcement of regulation on water resources, particularly on stream quality. A set of criteria and categories, based on a quartile scale, was proposed to quantify the subindex for law enforcement (as shown in Table 4).

\section{INDEX INTERPRETATION}

Index interpretation is important to better understand the sub-index value and the aggregated index value. For WJWSI, the interpretation for sub-indices and their aggregated index is based on the quartile scale. Using this scheme, the WJWSI maximum value of 100 and the minimum value of 0 are classified as shown in Table 5. The performance classification is used as the basis for relevant priority action. The Performance reflects the condition of issue(s) related to an indicator, a sub-indicator or the overall water resource condition in a particular time of assessment. The Priority of Action reflects the priority of actions required to address the issues related to respective indicators and sub-indicators.

\section{ANALYSIS AND RESULTS}

Following sub-sections present the details for calculating the sub-index values of the 13 indicators and subindicators. The results overview of the calculation is shown in Table 6.

Water Availability - According to Falkenmark (2004), the maximum amount of water available for human use is approximately $60 \%$ of the total rainfall, and this amount is used in WJWSI application. This amount is then divided by the total population in the catchment to obtain the actual value of Water Availability, which was calculated as 587 $\mathrm{m}^{3} /$ person/year. Then, Eq. 1 was used to calculate the sub-index for Water Availability, and found that it was 7.28. The low sub-index is caused by the large population living within the catchment. Recently the big cities in the catchment, such as Bandung, Depok and Bogor, have attracted people from other areas. Currently, there is no appropriate regulation to prevent this growing influx of people to these areas.
Table 6. Sub-index values of WJWSI Indicators and Sub-indicators

\begin{tabular}{|l|c|c|c|c|c|}
\hline $\begin{array}{c}\text { Indicator/sub- } \\
\text { indicator }\end{array}$ & Unit & $\begin{array}{c}\text { Actual } \\
\text { Value }\end{array}$ & Sub-index & Performance & $\begin{array}{c}\text { Priority of } \\
\text { Action }\end{array}$ \\
\hline Water Availability & $\mathrm{m}^{3} / \mathrm{cap} / \mathrm{yr}$ & 587.32 & $7.28^{\mathrm{a}}$ & Poor & High \\
\hline Land Use Changes & $\%$ & 84.68 & $84.68^{\mathrm{a}}$ & Good & Low \\
\hline Water Quality & - & -96.1 & $0.00^{\mathrm{b}}$ & Poor & High \\
\hline Water Demand & $\%$ & 23.04 & $56.54^{\mathrm{b}}$ & Medium-Good & Medium-Low \\
\hline Coverage & $\%$ & 34.96 & $43.70^{\mathrm{a}}$ & Poor-Medium & High-Medium \\
\hline Water Loss & $\%$ & 40.10 & $0.00^{\mathrm{b}}$ & Poor & High \\
\hline $\begin{array}{l}\text { Information } \\
\text { Disclosure }\end{array}$ & - & - & $37.27^{\mathrm{c}}$ & Poor-Medium & High-Medium \\
\hline $\begin{array}{l}\text { Governance } \\
\text { Structure }\end{array}$ & - & - & $35.00^{\mathrm{d}}$ & Poor-Medium & High-Medium \\
\hline Education & $\%$ & 14.19 & $14.19^{\mathrm{a}}$ & Poor & High \\
\hline Poverty & $\%$ & 15.23 & $23.87^{\mathrm{b}}$ & Poor & High \\
\hline Health Impact & $\begin{array}{c}\text { (cases/1000 } \\
\text { opp }\end{array}$ & 0.99 & $50.60^{\mathrm{b}}$ & Medium-Good & Medium-Low \\
\hline Sanitation & $\%$ & 61.86 & $61.86^{\mathrm{a}}$ & Medium-Good & Medium-Low \\
\hline Law Enforcement & - & - & $40.00^{\mathrm{e}}$ & Poor-Medium & High-Medium \\
\hline
\end{tabular}

\begin{tabular}{|c|c|c|}
\hline $\begin{array}{c}\text { Aggregated index and } \\
\text { Sub-index values }\end{array}$ & Performance & Priority of Action \\
\hline $0-<25$ & Poor & High \\
\hline $25-<50$ & Poor - Medium & High - Medium \\
\hline $50-<75$ & Medium - Good & Medium - Low \\
\hline $75-100$ & Good & Low \\
\hline
\end{tabular}

Table 3. Sub-index for Governance Structure

\begin{tabular}{|l|c|}
\hline \multicolumn{1}{|c|}{ Criteria } & Sub-index \\
\hline $\begin{array}{l}\text { Only few institutions that are responsible for managing } \\
\text { water resources have clear structures }\end{array}$ & $0-<25$ \\
\hline $\begin{array}{l}\text { All institutions that are responsible for managing water } \\
\text { resources have clear structures }\end{array}$ & $25-<50$ \\
\hline $\begin{array}{l}\text { Structure of the institutions are clear, but overlaps of } \\
\text { tasks occur }\end{array}$ & $50-<75$ \\
\hline $\begin{array}{l}\text { Clear structure and no overlaps of tasks among different } \\
\text { institutions }\end{array}$ & $75-100$ \\
\hline
\end{tabular}

Table 4. Sub-index for Law Enforcement

\begin{tabular}{|l|c|}
\hline \multicolumn{1}{|c|}{ Criteria } & Sub-index \\
\hline Procedure for enforcement is not available & $0-<25$ \\
\hline $\begin{array}{l}\text { Procedure for enforcement is available, but no supporting } \\
\text { resources (human, budget) }\end{array}$ & $25-<50$ \\
\hline $\begin{array}{l}\text { Procedure for enforcement and supporting resources } \\
\text { (human, budget) are available, but lack in implementation }\end{array}$ & $50-<75$ \\
\hline $\begin{array}{l}\text { Procedure for enforcement and supporting resources } \\
\text { (human, budget) are available, and implemented }\end{array}$ & $75-100$ \\
\hline
\end{tabular}

Table 5. Interpretation of Sub-index and Aggregated Index 
Land Use Changes - The sub-index for Land Use Changes was obtained by calculating the percentage of identified conservation areas within the catchment, which are supported with necessary planning documents. It was found that as much as $84.68 \%$ of the total conservation area was supported with necessary planning documents. Using Eq. 1, the sub-index for this indicator was calculated as 84.68.

Water Quality - The actual value of Water Quality was obtained by calculating the Storet value (Cude, 2001) for available 10 sampling points of water quality along the Citarum river. In the year of 2008, the average Storet value for those 10 sampling points was -96.1. Using Eq. 2, the sub-index for the Water Quality indicator was calculated as 0 . Low quality of water is caused by different factors. The major factor is the pollution from various activities along the rivers, particularly from domestic and industrial discharges. Lack of awareness by the general public on the quality of water has resulted in daily discharges of large amounts of pollutants into the rivers. This situation is worsened by the inadequacy of law enforcement by relevant authorities.

Water Demand - The first step to obtain the actual value of the Water Demand indicator was to sum up water used for different purposes, which were domestic, public facility, irrigation and industry uses. Then, this sum was expressed as a percentage of the availability of water resources for the catchment to obtain the actual value of the Water Demand indicator. For the Citarum catchment in 2008, this was calculated as 23.04\%. The sub-index for this indicator was, then, computed using Eq. 2 as 56.54.

Coverage - Within the Citarum catchment, there are 12 water service providers. The actual value of the coverage indicator was obtained by considering the ratio of the total population covered by the pipeline distributions of water companies to the total population within the catchment. Once this actual value was obtained (34.96\%), the sub-index for Coverage was calculated using Eq. 1 as 43.70.

Water Loss - The actual value of the Water Loss indicator was obtained by considering the average loss of water both in the water production and the water distribution of all 12 water service providers. In 2008, this was calculated as $40.10 \%$. After the actual value was obtained, the sub-index for Water Loss indicator was calculated using Eq. 2 as 0. The sub-index value for Water Loss shows that all water companies in the catchment suffer from high level of water loss.

Information Disclosure - The sub-index for the Information Disclosure considered the availability and accessibility of key data, and their regular updates. The key data includes rainfall, population, water quality, water use, water distribution coverage, water losses, education, poverty, sanitation, water-borne diseases and land use. Once the above data were obtained, they were assessed using the criteria in Table 2. For the Citarum catchment, most of these available data were not accessible by the public through the internet. The sub-index value for this indicator was assessed as 37.27.

Governance Structure - Clarity of the structures and their job descriptions, identification of any tasks overlapping among those institutions are the criteria to obtain the sub-index for this indicator, as presented in Table 3. The analysis for the Citarum catchment in 2008 shows that only few institutions, which are responsible for the management of water resource issues in the Citarum catchment, have clear institutional structure and job descriptions. In some cases, overlaps of tasks occur among different institutions. For these reasons, the sub-index for governance structure was assessed as 35.

Education - The actual value of the Education indicator was obtained by calculating the percentage of people in the Citarum catchment who have completed primary education. In 2008, this was calculated as $14.19 \%$. The sub-index of the Education indicator was then calculated using Eq. 1 as 14.19.

Poverty - The actual value of Poverty in the Citarum catchment was calculated using the percentage of people under the poverty standard, defined by the Indonesian national government. This standard is known as the poverty line, which is updated once every three years. In 2008, the poverty line for West Java is Rp. $182,636.00$ per person/month (approximately AUD 20.29). The percentage was calculated as $15.23 \%$. Using this percentage value, the sub-index of the Poverty indicator was computed using Eq. 2 as 23.87.

Health Impact - For the Health Impact indicator, its actual value was calculated by considering the number of haemorrhagic dengue cases for every 1000 people. In the Citarum catchment for 2008, the actual value was calculated as 0.99. The sub-index was then calculated using Eq. 2 as 50.60.

Sanitation - The actual value of the Sanitation indicator was obtained by calculating the percentage of people having basic sanitation facilities, in accordance with the national regulation on the minimum standard of sanitation facilities (MDG Indonesia Team, 2007). The actual value was calculated as $61.86 \%$. Once this value was obtained, the sub-index was calculated using Eq. 1 as 61.86 . This value reflects that there were still around $40 \%$ of the population, about 4 million, who had no access to basic sanitation facilities. 
Law Enforcement - The sub-index for the Law Enforcement indicator was obtained by assessing the availability of procedures to enforce water-resource-related policies and regulations, compared with the actual implementation of the procedures. Currently, the West Java EPA already has procedures for regulation enforcement, but is not fully implemented due to lack of support from other relevant institutions. For this reason, the sub-index for the Law Enforcement indicator in the Citarum catchment (based on the detailed criteria in Table 4) was estimated as 40.

\section{RECOMMENDATIONS}

Better quality and management of water resources in the Citarum catchment can be best achieved by providing higher priority to the improvement of the indicators and sub-indicators that are Poor in their Performance (which are Water Availability, Water Quality, Education, Water Loss and Poverty). The following sub-sections provide recommendations to improve the poorly performing indicators and subindicators to achieve at least a sub-index value of 25, and to move up to the next-better performance (PoorMedium).

Water Availability - To increase the performance at least to Poor-Medium (or a sub-index value of 25), the actual availability needs to be increased from $587 \mathrm{~m}^{3} /$ year to at least $812 \mathrm{~m}^{3} /$ person/year. The only way to increase the availability of water resources in the area is by managing the population. One way of managing the population is to create centres of activities in less-dense population areas within the West Java province. At this stage, these centres of activities are concentrated in one of the cities in Citarum catchment, the Bandung City (i.e. the capital city of West Java Province). Creating these centres of activities in other areas will significantly reduce the motivation of people to migrate to Bandung City and other highly populated areas in the Citarum catchment. Another way to manage the population in the area is through the reintroduction of the 'transmigration' program, which was initiated in the early 60s (Gondowarsito, 1990). Through this program, people are encouraged to be relocated to less-dense areas. They are given a piece of land, housing and establishment allowance to start a new life in a less-dense area.

Water Quality - In order to move to Poor-Medium performance, the actual value of the Water Quality needs to be increased from -96.1 to -8.06 . Poor quality of water in the catchment was mainly caused by the lack of awareness of the community on the importance of the rivers. To address this issue, the government, the West Java EPA and the community groups need to develop programs to improve community awareness on water resources. To be successful, targets of these programs should be clearly stated and the progress regularly monitored. Along with the community awareness programs, relevant authorities also need to enforce laws and regulations on river quality. To do this, close monitoring on the operation of wastewater treatment plants is required to ensure that industrial wastewater discharges meet the designated standard.

Education - The actual value of the Education sub-indicator needs to be increased from $14.19 \%$ to $25 \%$ to achieve the Poor-Medium performance. In the last few years, the Ministry of Education of Indonesia has introduced programs to improve the quality of primary education in Indonesia. The programs include the exemption of education fee for all primary students, providing most elementary schools with necessary books and improving the quality of school infrastructure. However, up to this stage, these programs have not yet been fully implemented. There are still cases where schools collect money from the students by giving various excuses. Consequently, students from low income families are prevented to enrol in these schools. Therefore, to effectively improve the quality of primary education, these obstacles need to be eliminated.

Water Loss - In order to move to Poor-Medium performance, the average actual value of Water Loss of water service providers in the Citarum catchment needs to be reduced from $40.10 \%$ to $18.50 \%$. The water losses of water service providers (WSPs) in Indonesia, including in the Citarum catchment, were caused by both physical and non-physical factors. The physical causes that lead to water losses are leakages in water treatment plants, transmission systems and distribution systems. As for the non-physical causes, the losses mainly come from unbilled consumption, inaccuracies of customer metering and illegal connections. Higher priorities should be given to reduce the non-physical losses as programs for reducing non-physical losses are more cost-efficient. It is believed that non-physical losses contribute approximately $50 \%$ to the total water losses occurring in West Java WSPs (Yuwono, 2009).

Poverty - The WJWSI results indicate that a decrease of $0.43 \%$ of its actual value is needed to move to Poormedium performance. In the last few years, the local, the provincial and the national governments have launched programs such as 'direct cash assistance' and 'cheap rice' to reduce the poverty level. The authorities reported that these programs have significantly reduced poverty in most provinces in Indonesia. However, such programs benefited the poor, only for a short period of time, since some of these programs 
had been terminated. Once the programs terminated, the poverty level had increased. Also, due to lack of monitoring, it was found that some of the donations did not reach the poor people. Thus, in the future, closer monitoring on the implementation and the continuation of these programs is crucial to ensure that benefits are received by the poor people.

\section{CONCLUSIONS}

In the last decade, water authorities in West Java in Indonesia have struggled to implement important water improvement programs due to lack of tools for prioritisation of water-related issues and their respective programs. To address this, a water sustainability index for West Java called West Java Water Sustainability Index (WJWSI) was developed. The application of WJWSI to the Citarum catchment in West Java, which is presented in this paper, has provided the information on the current water resource conditions in the catchment. It also prioritised the important water issues in the catchment. The results showed that the WJWSI was able to provide both the general status of the water resource condition, and the specific status on different indicators and sub-indicators in the Citarum catchment. The general performance of the water resource condition in 2008 in the Citarum catchment was evaluated as Poor-Medium, shown by the final index value of 35.00. Out of thirteen sub-indices, five of them were evaluated as poor. They are the subindices for Water Availability, Water Quality, Water Loss, Education and Poverty indicators and subindicators. To improve the sub-index values of these indicators and sub-indicators, recommendations are provided to the relevant authorities in the Citarum catchment.

\section{REFERENCES}

Chaves, H., and Alipaz, S. (2007). An integrated indicator based on basin hydrology, environment, life, and policy: the Watershed Sustainability Index. Water Resources Management, 21(5), 883-895.

Cude, C. G. (2001). Oregon water quality index: a tool for evaluating water quality management effectiveness. Journal of the American Water Resources Association, 37(1), 125-138.

Delbecq, A. L., Ven, A. H. V. d., and Gustafon, D. H. (1975). Group techniques for program planning: a guide to nominal group and Delphi processes. Illinois: Glenview.

Falkenmark, M., and Rockström, J. (2004). Balancing water for humans and nature: the new approach in ecohydrology. London: Earthscan.

Gondowarsito, R. (1990). Transmigrasi bedol desa: inter-island village resettlement from Wonogiri to Bengkulu. Bulletin of Indonesian Economic Studies, 26(1), 48-68.

Juwana, I., Perera, B., and Muttil, N. (2010a). A water sustainability index for West Java - Part 1: developing the conceptual framework. Water science and technology: a journal of the International Association on Water Pollution Research, 62(7), 1629-1640.

Juwana, I., Perera, B., and Muttil, N. (2010b). A water sustainability index for West Java - Part 2: refining the conceptual framework using Delphi technique. Water science and technology: a journal of the International Association on Water Pollution Research, 62(7), 1641-1652.

Loucks, D. P., Stakhiv, E. Z., and Martin, L. R. (2000). Sustainable water resources management. Journal of Water Resources Planning and Management, 126(2), 43-47.

MDG Indonesia Team. (2007). Achivement of MIllenium Development Goals Indonesia Jakarta: National Planning and Development Board.

Policy Research Initiative. (2007). Canadian Water Sustainability Index Retrieved 5 July 2007, from http://policyresearch.gc.ca/doclib/SD_PR_CWSI_web_e.pdf

Sullivan, C. (2002). Calculating a Water Poverty Index. World Development, 30(7), 1195-1210.

Sullivan, C., and Meigh, J. (2007). Integration of the biophysical and social sciences using an indicator approach: addressing water problems at different scales. Water Resources Management, 21(1), 111128.

Toward, J. I., and Ostwald, S. K. (2002). Brief report: exploring mental health service needs for the elderly: results of a modified Delphi study. Community Mental Health Journal, 38(2), 141-149.

Wangsaatmaja, S. (2004). Dampak konversi lahan terhadap rezim aliran air permukaan serta kesehatan lingkungan (the effects of land conversion on river regime and environmental health). Doctoral, Bandung Institute of Technology, Bandung.

Yuwono, B. (2009). Departemen PU minta PDAM turunkan tingkat kebocoran air (The need to reduce water loss of water service providers in Indonesia) Retrieved 12 June, 2008, from http://ciptakarya.pu.go.id/index.php?option=com_content\&task=view\&id=1216 